ISSN 2413-0877 Volume 2 (2015) 361

The 3rd International Conference on Biological Science 2013

(The 3rd ICBS-2013)

\title{
BANANA LEAVES QUALITY OF Musa balbisiana Colla. AND Musa paradisiaca L. BASED ON ANATOMICAL STRUCTURE
}

\author{
Maryani $^{1}$ and Puput Pratiwi ${ }^{2}$ \\ ${ }^{1}$ Laboratory of Plant Structure and Development, Faculty of Biology, Universitas Gadjah Mada. \\ ${ }^{2}$ Alumnus Faculty of Biology UGM. \\ Address of Correspondence Jl. Teknika Selatan, Sekip Utara, Yogyakarta, 55281, Indonesia. \\ e-mail: mmyani@yahoo.com
}

\begin{abstract}
Indonesia is the main centre of banana biodiversity. Banana is preferred because of its high nutrient content and economical value. Besides, banana leaves, particularly from "Klutuk" banana (Musa balbisiana Colla.) is also well-known used as traditional wrapper of cakes and foods. The objective of this research was to know and to compare the anatomical structure of Musa balbisiana Colla. and Musa paradisiaca L. leaves, and their anatomical characters as quality indication of banana leaves used as cakes and foods wrapper. Cross sections of banana leaves were prepared using free hand section and paraffin embedding methods. Leaf clearing method was used to prepare upper and lower epidermal tissue slides. Parameters used were the arrangement of cells/tissues, length and width of vascular bundles, mesophyll thickness, the thickness of schlerenchyma tissue, the number of laticiferous and tanin cells, and stomata indexs. The data were analyzed using Analysis of Variance (Anova) continued by Duncan test at level $5 \%$. The results showed that the anatomical structure of M.balbisiana Colla. and M. paradisiaca L. leaves consisted of epidermis, hypodermis, mesophyll, and vascular bundles. The supporting tissues were composed of sclerenchyma located at upper and lower side of vascular bundle. The number of cell layers composing upper and lower hypodermis; stomata number, stomata index, the length and width of stomata; the thickness of vascular bundles; the thickness of layers composing adaxial and abaxial mesophyll; the thickness of schlerenchyma layers and width of schlerenchyma tissue at vascular bundle as well as laticiferous and tannin cell were found differently between M. balbisiana Colla. and M. paradisiaca $L$. The values of meshophyll thickness, length and width of vascular bundle, the thickness of schlerenchyma tissue, the number of laticiferous cells and the number of tanin cells were higher for M. paradisiaca $L$ than in $M$. balbisiana Colla. The smaller the thickness of schlerenchyma layers and the width of schlerenchyma tissue at vascular bundle as well as the less number of laticiferous and tannin cells were assumed to be correlated with the good quality of $M$. balbisiana Colla leaves as foods and cakes wrapper.
\end{abstract}

Keywords: anatomy, banana leaves, Musa balbisiana Colla., Musa paradisiaca L.

ISSN 2413-0877 (C) 2015 The Authors.

Published by KnowledgeE Publishing Services This is an open access article under the CC BY-NC-ND license (http://creativecommons.org/licenses/by-nc-nd/4.0)

Selection and Peer-review under responsibility of the 3rd ICBS-2013

Doi http://dx.doi.org/10.18502/kls.v2i1.174 